\title{
Prediksi Peluang Kelulusan Mahasiswa PTIK dalam Uji Kompetensi Microsoft Office 2010 menggunakan Teori Rough Set
}

\author{
Karmila Suryani* \\ Jurusan Pendidikan Teknik Informatika dan Komputer \\ FKIP Universitas Bung Hatta \\ (corresponding author) karmilasuryani.ptik@gmail.com *
}

\begin{abstract}
PTIK and Microsoft Partner Joint Partnership has held Microsoft Office 2010 Competency Test, covering the subjects among others Excell, Power Point dan Word. In this Competency Test, Microsoft Partner has previously trained and provided the students with an international standard curriculum material tailored in such a way to meet the need of business world. The test showed that there are still some students of PTIK who failed to pass the test at every batch. This article aim to see decision making order in determination of opportunity pass student of PTIK in interest test of Microsoft 2010. The level of passing the test of PTIK students in the three subjects can be predicted by using Rough Set Theory, that is 4 who surely pass 100\%, 8 people with probability $67 \%$ and also 6 people with probability $33 \%$.
\end{abstract}

Key words. Level of Passing Microsoft Office 2010 Test, Rough Set Theory, Rule of Decision.

Intisari - Kerjasama PTIK dan Microsoft partner telah melakukan uji kompetensi penguasaan Microsoft office 2010, diantaranya Excell, Power Point dan Word. Microsoft partner telah menyusun materi kurikulum berstandar internasional berdasarkan kebutuhan dunia usaha untuk uji kompetensi. Dengan uji kompetensi tersebut masih terdapat mahasiswa yang tidak lulus disetiap angkatan. Tulisan ini bertujuan untuk melihat aturan pengambilan keputusan dalam penentuan peluang lulus mahasiswa PTIK dalam uji kompetensi Microsoft 2010. Melalui teori Rough Set maka dapat diprediksi tingkat kelulusan mahasiswa PTIK dalam menguasai ketiga materi, yaitu 4 orang yang pasti lulus $100 \%, 8$ orang dengan peluang $67 \%$ serta 6 orang dengan peluang $33 \%$.

Kata kunci. Tingkat kelulusan Microsoft Office 2010, Teori Rough Set, Rule Keputusan.

\section{PENDAHULUAN}

Perguruan Tinggi merupakan sebuah lembaga pendidikan untuk menyelenggarakan pendidikan tinggi bagi tamatan sekolah menengah atas. Mahasiswa sering disebut dengan kelompok masyarakat yang memiliki intelektual yang lebih luas dibandingkan dengan kelompok seusia mereka yang bukan mahasiswa ataupun kelompok usia lain dibawah mereka. Dengan intelektual tinggi yang mereka miliki maka mereka mampu untuk menghadapi dan mencari solusi dalam permasalahan yang terjadi dalam kehidupan sehari-hari agar mereka dapat bersaing di dunia kerja. Berdasarkan Peraturan Presiden Republik Indonesia Nomor 8 Tahun 2012 tentang Kerangka Kualifikasi Nasional Indonesia yang menjadi dasar untuk mengembangkan sebuah ukuran kualifikasi lulusan pendidikan di Indonesia dalam bentuk sebuah kerangka kualifikasi, yang kemudian dikenal dengan Kerangka Kualifikasi Nasional Indonesia (KKNI) dan menjadi sebuah tonggak sejarah baru bagi dunia pendidikan tinggi di Indonesia agar menghasilkan sumber daya manusia berkualitas dan bersaing di tingkat global seiring dengan MEA.

Universitas Bung Hatta Padang merupakan perguruan tinggi swasta di Sumatera Barat ikut serta dalam upaya menciptakan lulusan yang berkualitas. Melalui program studi Pendidikan Teknik Informatika dan Komputer (PTIK), Iulusan dipersiapkan untuk dapat bersaing dengan dunia luar melalui penguasaan Teknologi Informasi dan Komunikasi. Sementara itu, kebijakan Dikti menyatakan bahwa perguruan tinggi harus dapat mempersiapkan lulusannya agar dapat bersaing di pasar kerja yang kompetitif. Hal ini karena terjadinya ketidakseimbangan antara permintaan dengan penawaran, serta kualitas Sumber Daya Manusia (SDM) yang dihasilkan sesuai dengan kebutuhan dunia kerja. Penguasaan keterampilan komputer merupakan salah satu komponen TIK yang menunjukkan kualitas SDM yang siap pakai. 
Perkembangan Teknologi Informasi dan Komunikasi (TIK) telah mempengaruhi berbagai aspek kehidupan masyarakat yang mendorong terciptanya era baru dari era industri ke era Informasi. Referensi [3] menyatakan bahwa masyarakat era informasi lebih memusatkan pada aset pengetahuan dibandingkan dengan aset modal. Hal ini mengisyaratkan semua komponen masyarakat harus terbiasa dengan TIK. Dalam upaya mempersiapkan mahasiswa yang mampu bersaing dalam era pasar bebas, maka jurusan PTIK telah menjalin kerjasama dengan Microsoft Partner Surabaya untuk melakukan uji kompetensi tentang kemampuan dasar komputer yaitu microsoft Office meliputi Mocrosoft office Excell, Power Point dan Word. Materi uji kompetensi tersebut sesuai dengan kurikulum Microsoft yang berlaku secara Internasional.

Terdapat hampir 60 orang yang sudah disertifikasi Microsoft atau 3 angkatan. Namun masih ada yang belum Iulus uji kompetensi, hal ini karena belum dikuasainya materi secara baik. Untuk setiap angkatan, minimal terdapat 3 (tiga) orang yang tidak lulus sertifikasi Microsoft. Oleh karenanya perlu dilakukan perhitungan yang akurat untuk memprediksi peluang lulus mahasiswa yang mengikuti sertifikasi Microsoft. Metoda yang sangat cocok untuk menentukan tingkat kelulusan sertifikasi Microsoft adalah menggunakan Teori Roughset. Teori Rough set dikembangkan oleh Zdzislaw Pawlak pada awal tahun delapan puluhan. Teori ini muncul karena adanya Rough pada suatu himpunan, dimana dalam teori Rough set, data dapat direpresentasikan dalam dua system yaitu system informasi dan system keputusan yang ada pada [5].

Penggunaan teori Rough set yang pernah penulis gunakan diantaranya dalam menganalisa kelayakan pemberian kredit penjualan ban Good year[6] dan dalam penentuan distribusi persentase terbaik bagi mata kuliah di Jurusan PTIK Universitas Bung Hatta[7]. Sementara aplikasi yang pernah digunakan dalam penentuan kebijakan laka Lantas di kabupaten Sleman[2] dan penerapannya pada laka lantas sepeda motor di kota Magelang[1]. Masih banyak lagi aplikasi teori Rough Set dalam penyelesaian masalah dalam bidang-bidang diantaranya seperti medicine, pharmacology, business, banking, market research, engineering design, meteorology, vibration analysis, conflict analysis, image processing dan decision analysis, software security dan bidang lainnya.

\section{METODE PENELITIAN}

\section{A. Jenis penelitian}

Jenis penelitian ini adalah penelitian deskriptif yang menganalisa dan mendeskripsikan melalui instrumen yang tepat untuk memperoleh tujuan yang hendak dicapai. Menurut [4], penelitian deskriptif merupakan metode penelitian yang berusaha menggambarkan objek atau subjek yang diteliti sesuai dengan apa adanya, dengan tujuan menggambarkan secara sistematis fakta dan karakteristik objek yang diteliti secara tepat. Fakta yang diteliti dalam penelitian ini adalah pelatihan Microsoft Office 2010 yang dirancang oleh microsoft partner sangat efektif untuk diberikan ke mahasiswa.

\section{B. Populasi dan Sampel}

Dalam penelitian ini populasi yang diteliti adalah seluruh mahasiswa PTIK-FKIP Universitas Bung Hatta yang sudah mendapatkan ID dari Microsoft partner sebanyak 60 Orang. Karena jumlah populasinya kurang dari 100 maka sampel penelitian adalah semua populasi. Pemilihan sampel ini dilakukan dengan menggunakan teknik bertujuan atau purposive sampling. Dengan teknik purposive sampling pemilihan kelas sampel dilakukan untuk memperoleh informasi yang relevan dengan tujuan penelitian. Sebagaimana dipaparkan dalam [4] bahwa untuk menentukan seseorang jadi sampel atau tidak didasarkan pada tujuan tertentu, misalnya dengan pertimbangan profesional yang dimiliki oleh si peneliti dalam usahanya memperoleh informasi yang relevan dengan tujuan penelitian. Jadi sampel dalam penelitian ini berjumlah 18 orang.

\section{Teknik Analisa Data}

Analisis data bertujuan untuk melihat berapa peluang mahasiswa lulus dalam pelaksanaan uji kompetensi Microsoft office 2010. Untuk menemukan sebuah knowledge tentang peluang kelulusan dengan teori Rough Set dilakukan langkah-langkah seperti gambar 1. 


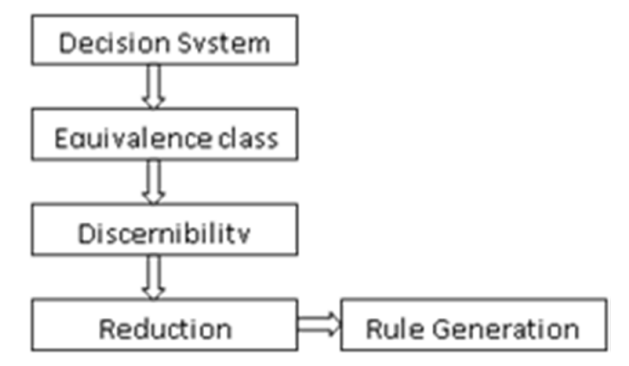

Gambar 1. Proses Penemuan Knowledge dengan Rough Set

Uraian untuk masing-masing langkah menurut gambar 1 adalah sebagai berikut:

a. Decision System

Decision system adalah information system dengan atribut tambahan yang dinamakan dengan decision attribute, dalam data mining dikenal dengan nama kelas atau target. Atribut ini merepresentasikan hasil dari klasifikasi yang diketahui.

Decision system merupakan fungsi yang mendeskripsikan information system yaitu

$\mathrm{DS}=\mathrm{f}(\mathrm{U},(\mathrm{A}, \mathrm{C}))$

dimana :

$\mathrm{U}=$ objek

$A=$ atribut kondisi

$\mathrm{C}=$ atribut keputusan

b. Equivalence Class

Equivalence Class adalah mengelompokkan objek-objek yang mempunyai nilai atribut yang sama menjadi satu bagian.

c. Discernibility Matrix

Discernibility Matrix terdiri dari sekumpulan attribute yang berbeda antara objek Xi dan Xj. Pada discernibility matrix ini akan dibandingkan isi sebuah atribut antara suatu objek dengan objek yang lainnya. Dalam proses membandingkan ini yang diperhatikan hanya atribut kondisinya saja, yang mana jika nilai atributnya sama maka tidak menghasilkan suatu nilai tetapi jika nilai atribut yang dibandingkan berbeda maka akan menghasilkan suatu nilai.

d. Discernibilty Matrix Modulo D

Sama seperti Discernibility Matrix, pada Discernibilty Matrix Modulo D juga terdiri dari sekumpulan attribute yang berbeda antara objek Xi dan Xj. Proses untuk menghasilkan Discernibility Matrix Modulo D ini juga membandingkan isi sebuah atribut suatu objek dengan objek yang lainnya. Perbedaan dengan Discernibility Matrix adalah dalam proses membandingkannya yang diperhatikan tidak hanya atribut kondisinya saja, tetapi juga atribut keputusannya. Yang mana jika nilai atributnya sama maka tidak menghasilkan suatu nilai, tetapi jika nilai atribut yang bandingkan berbeda maka akan menghasilkan nilai.

e. Reduct

Reduct adalah penyelesaian atribut minimal (interesting attribute) dari kesimpulan atribut kondisi dengan menggunakan Prie Implicant fungsi Boolean. Kumpulan dari semua prime implicant mendeterminasikan sets of reduct. Discernibility matrix modulo $D$ pada Tabel 10 dapat ditulis sebagai formula CNF

f. Generating Rules

Generating Rules adalah suatu metode Rough Set untuk menghasilkan rules/knowledge berdasarkan equivalence class dan reduct, Generating Rules dapat juga dikatakan sebagai suatu algoritma dari Data Mining, yang mana nantinya dari proses Generating Rules ini akan dihasilkan suatu rules/knowledge yang dapat digunakan dalam sebuah pengambilan keputusan.

\section{HASIL DAN PEMBAHASAN}

Berdasarkan data sampel yang diperoleh dari hasil uji kompetensi Microsoft untuk mahasiswa PTIK Universitas Bung Hatta, menurut teori Roughset, langkah pertama yang dilakukan adalah proses pengelolaan data mentah ke dalam data mining dengan langkah-langkah sebagai berikut; 


\section{A. Proses Transformasi Data}

Proses transformasi data merupakan proses persiapan merubah data dari data mentah(raw data) ke bentuk lain sehingga dapat digunakan untuk proses prediksi. Sebelumnya semua data yang menjadi sampel dalam penelitian diungkapkan dalam tabel 1 berupa information system.

Tabel 1. Information System

\begin{tabular}{|c|l|c|c|c|c|}
\hline \multirow{2}{*}{ No. } & \multirow{2}{*}{ Nama Peserta } & \multicolumn{3}{c|}{ Nilai } & \multirow{2}{*}{ Keterangan } \\
\cline { 3 - 5 } & & Word & Excel & PP & \\
\hline 1 & MUHAMMAD IKRAM JASMAN & 86 & 66 & 70 & Lulus \\
\hline 2 & HIDAYATUL IKHSAN & 73 & 45 & 73 & Lulus \\
\hline 3 & MEGA KURNIA & 66 & 35 & 35 & Gagal \\
\hline 4 & VAHELGA RESDIA & 45 & 20 & 80 & Gagal \\
\hline 5 & OKTRIYANISHA LUBIS & 25 & 55 & 83 & Lulus \\
\hline 6 & MUTHYA YURVIALLEY & 43 & 78 & 50 & Lulus \\
\hline 7 & RAHMADEWI YUNAS & 66 & 20 & 43 & Gagal \\
\hline 8 & PUTRI NURMADANI & 51 & 51 & 50 & Lulus \\
\hline 9 & MUSLIM JAMIL M & 66 & 55 & 55 & Lulus \\
\hline 10 & SISKA ASRA & 60 & 34 & 55 & Gagal \\
\hline 11 & KARTIKA ENZA ROSADY & 51 & 30 & 51 & Gagal \\
\hline 12 & DELSI FITRIATI & 85 & 40 & 43 & Lulus \\
\hline 13 & SISWANTO & 86 & 10 & 51 & Gagal \\
\hline 14 & TRIO BOYKE & 76 & 60 & 80 & Lulus \\
\hline 15 & GUSTRI WANDI & 86 & 36 & 86 & Lulus \\
\hline 16 & AGUNG MUHAMAD RIDWAN & 70 & 76 & 35 & Lulus \\
\hline 17 & ANDIKA PARDI & 66 & 45 & 35 & Gagal \\
\hline 18 & NIKEN RESKIA DINA & 66 & 55 & 66 & Lulus \\
\hline
\end{tabular}

Tabel 1 menjelaskan bahwa data sampel direpresentasikan menjadi atribut kondisi dan atribut keputusan. Atribut keputusan dari decision data adalah peluang lulus, sedangkan atribut kondisinya adalah nilai Word, nilai Excel dan nilai Power Point (PP). Proses Trasformasi data selanjutnya dilakukan dengan langkah diantaranya:

a. Mengkalasifikasi atribut kondisi dan atribut keputusan menggunakan metode unary encoding dan categorical data adalah sebagai berikut:

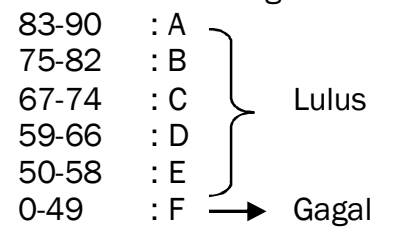

Keterangan

Rata-rata < 50 (gagal) : 0 dan

Rata-rata $\geq 50$ (lulus) : 1 .

b. Atribut kondisi yang digunakan diberi simbol;

$\begin{array}{lll}\text { Nilai Word } & : \mathrm{K} \\ \text { Nilai Excel } & : \mathrm{L} \\ \text { Nilai Power Point } & : \mathrm{M}\end{array}$

Atribut Keputusan (Peluang Lulus) dengan simbol : N

Berdasarkan tabel 1, maka data ditransformasi yang disebut hasil dari transformasi data 1 menurut atribut kondisi dan Keputusan seperti terlihat pada tabel 2. 
Tabel 2. Transformasi Data 1

\begin{tabular}{|c|c|c|c|c|}
\hline Sampel & K & L & M & N \\
\hline S1 & A & D & C & $?$ \\
\hline S2 & C & F & C & $?$ \\
\hline S3 & D & F & F & $?$ \\
\hline S4 & F & F & B & $?$ \\
\hline S5 & F & E & A & $?$ \\
\hline S6 & F & B & F & $?$ \\
\hline S7 & D & F & F & $?$ \\
\hline S8 & E & E & F & $?$ \\
\hline S9 & D & E & E & $?$ \\
\hline S10 & D & F & E & $?$ \\
\hline S11 & E & F & E & $?$ \\
\hline S12 & A & F & F & $?$ \\
\hline S13 & A & F & E & $?$ \\
\hline S14 & B & E & B & $?$ \\
\hline S15 & A & F & A & $?$ \\
\hline S16 & C & B & F & $?$ \\
\hline S17 & D & F & F & $?$ \\
\hline S18 & D & E & D & $?$ \\
\hline
\end{tabular}

Tabel 2 menjelaskan bahwa atribut kondisi (nilai Microsof Office word, Excel dan Power Point) sudah ditransformasikan menjadi K, L dan M sedangkan atribut keputusanya ditransformasikan dengan N. Proses Transformasi data 1 ini bertujuan untuk mendapatkan data equivalen class, dimana apabila ada sampel yang mempunyai atribut kondisi dan atribut keputusan sama maka dijadikan satu sampel saja. Selanjutnya dilakukan proses transformasi data 2 yakni dengan mengganti nilai yang ada atribut kondisi dan atribut keputusan dengan 0 dan 1 . Untuk nilai pada atribut kondisi bernilai 1 apabila kode dari data A sampai $E$ dan bernilai 0 apabila kode nilai dari data F, sementara atribut keputusannya (peluang Lulus) belum bisa diisi karena belum ditentukan berapa persentase peluang lulus dari masingmasing sampel. Transformasi data 2 dapat dilihat pada tabel tabel 3.

\begin{tabular}{|c|c|c|c|c|}
\hline \multicolumn{7}{|c}{ Tabel 3. Transformasi Data 2 } \\
\hline Sampel & K & L & M & N \\
\hline S1 & 1 & 1 & 1 & $?$ \\
\hline S2 & 1 & 0 & 1 & $?$ \\
\hline S3 & 1 & 0 & 0 & $?$ \\
\hline S4 & 0 & 0 & 1 & $?$ \\
\hline S5 & 0 & 1 & 1 & $?$ \\
\hline S6 & 0 & 1 & 0 & $?$ \\
\hline S7 & 1 & 0 & 0 & $?$ \\
\hline S8 & 1 & 1 & 0 & $?$ \\
\hline S9 & 1 & 1 & 1 & $?$ \\
\hline S10 & 1 & 0 & 1 & $?$ \\
\hline S11 & 1 & 0 & 1 & $?$ \\
\hline S12 & 1 & 0 & 0 & $?$ \\
\hline S13 & 1 & 0 & 1 & $?$ \\
\hline S14 & 1 & 1 & 1 & $?$ \\
\hline S15 & 1 & 0 & 1 & $?$ \\
\hline S16 & 1 & 1 & 0 & $?$ \\
\hline S17 & 1 & 0 & 0 & $?$ \\
\hline S18 & 1 & 1 & 1 & $?$ \\
\hline
\end{tabular}

Tabel 3 menujukan data pada atribut kondisi sudah ditransformasikan menjadi nilai 0 dan 1, untuk melengkapi isi dari atribut keputusan maka dikelompokan data dari sampel yang bernilai sama, seperti terlihat pada tabel 4. 
Tabel 4. Equivalence Class pada transformasi data 2

\begin{tabular}{|c|c|c|c|c|c|}
\hline $\begin{array}{c}\text { Equivalence } \\
\text { Class }\end{array}$ & $\mathbf{K}$ & $\mathbf{L}$ & $\mathbf{M}$ & $\mathbf{N}$ & Jml Objek \\
\hline EC1 & 1 & 1 & 1 & 1 & 4 \\
\hline EC2 & 1 & 0 & 1 & 2 & 8 \\
\hline EC3 & 1 & 0 & 0 & 3 & 6 \\
\hline
\end{tabular}

Proses perhitungan untuk melengkapi nilai atribut keputusan (E) sebagai berikut :

$$
\begin{aligned}
& \mathrm{EC}_{1}=\frac{1+1+1}{3} \times 100 \%=100 \%: 1 \\
& \mathrm{EC}_{2}=\frac{1+0+1}{3} \times 100 \%=67 \%: 2 \\
& \mathrm{EC}_{3}=\frac{1+0+0}{3} \times 100 \%=33 \% \quad: 3
\end{aligned}
$$

B. Proses Penemuan Knowledge dengan Rough Set

Setelah data direpresentasikan melalui proses transformasi data maka selanjutnya dilakukan pengolahan data dengan Rough Set yang langkah-langkahnya sebagai berikut;

a. Decision System

Decision System dari sampel dapat dilihat dari tabel 3 yaitu :

$$
\begin{aligned}
& >100 \%: \mathrm{S}_{1}, \mathrm{~S}_{9}, \mathrm{~S}_{14}, \mathrm{~S}_{18} \\
& >\quad 67 \%: \mathrm{S}_{2}, \mathrm{~S}_{5}, \mathrm{~S}_{8}, \mathrm{~S}_{10}, \mathrm{~S}_{11}, \mathrm{~S}_{13}, \mathrm{~S}_{15}, \mathrm{~S}_{16} \\
& >\quad 33 \% \quad: S_{3}, S_{4}, S_{6}, S_{7}, S_{12}, S_{17}
\end{aligned}
$$

b. Equivalence Class

Berdasarkan tabel 2 transformasi data 1 maka data atribut kondisi dan atribut keputusan bernilai sama $\mathrm{S}_{3}, \mathrm{~S}_{7}$ dan $\mathrm{S}_{17}$, sehingga data pada sampel tersebut dipilih satu saja sehingga hasil transformasi data 1 terlihat seperti tabel 5 Equivalence Class.

Tabel 5. Equivalence Class pada transformasi data 1
\begin{tabular}{|c|c|c|c|c|}
\hline EQ & K & L & M & N \\
\hline EC1 & A & D & C & 1 \\
\hline EC2 & C & F & C & 2 \\
\hline EC3 & D & F & F & 3 \\
\hline EC4 & F & F & B & 3 \\
\hline EC5 & F & E & A & 2 \\
\hline EC6 & F & B & F & 3 \\
\hline EC7 & E & E & F & 2 \\
\hline EC8 & D & E & E & 1 \\
\hline EC9 & D & F & E & 2 \\
\hline EC10 & E & F & E & 2 \\
\hline EC11 & A & F & F & 3 \\
\hline EC12 & A & F & E & 2 \\
\hline EC13 & B & E & B & 1 \\
\hline EC14 & A & F & A & 2 \\
\hline EC15 & C & B & F & 2 \\
\hline EC16 & D & E & D & 1 \\
\hline
\end{tabular}

Tabel 5 menunjukan bahwa sampel yang dijadikan penemuan knowledge baru berjumlah 16 buah, sehingga hasil transformsi data 1 dan transformasi data 2 dapat dibentuk seperti terlihat pada tabel 6 dan tabel 7 . 
Tabel 6. Hasil Transformasi Data 1

\begin{tabular}{|c|c|c|c|c|}
\multicolumn{7}{|c}{ Tabel 6. Hasil Transformasi Data 1 } \\
\hline Sampel & K & L & M & N \\
\hline S1 & A & D & C & 1 \\
\hline S2 & C & F & C & 2 \\
\hline S3 & D & F & F & 3 \\
\hline S4 & F & F & B & 3 \\
\hline S5 & F & E & A & 2 \\
\hline S6 & F & B & F & 3 \\
\hline S7 & E & E & F & 2 \\
\hline S8 & D & E & E & 1 \\
\hline S9 & D & F & E & 2 \\
\hline S10 & E & F & E & 2 \\
\hline S11 & A & F & F & 3 \\
\hline S12 & A & F & E & 2 \\
\hline S13 & B & E & B & 1 \\
\hline S14 & A & F & A & 2 \\
\hline S15 & C & B & F & 2 \\
\hline S16 & D & E & D & 1 \\
\hline
\end{tabular}

\begin{tabular}{|c|c|c|c|c|}
\multicolumn{7}{|c}{ Tabel 7. Hasil Transformasi Data 2} \\
\hline Sampel & $\mathbf{K}$ & $\mathbf{L}$ & $\mathbf{M}$ & $\mathbf{N}$ \\
\hline S1 & 1 & 1 & 1 & 1 \\
\hline S2 & 1 & 0 & 1 & 2 \\
\hline S3 & 1 & 0 & 0 & 3 \\
\hline S4 & 0 & 0 & 1 & 3 \\
\hline S5 & 0 & 1 & 1 & 2 \\
\hline S6 & 0 & 1 & 0 & 3 \\
\hline S7 & 1 & 1 & 0 & 2 \\
\hline S8 & 1 & 1 & 1 & 1 \\
\hline S9 & 1 & 0 & 1 & 2 \\
\hline S10 & 1 & 0 & 1 & 2 \\
\hline S11 & 1 & 0 & 0 & 3 \\
\hline S12 & 1 & 0 & 1 & 2 \\
\hline S13 & 1 & 1 & 1 & 1 \\
\hline S14 & 1 & 0 & 1 & 2 \\
\hline S15 & 1 & 1 & 0 & 2 \\
\hline S16 & 1 & 1 & 1 & 1 \\
\hline
\end{tabular}

\section{c. Discernibility Matrix}

Berdasarkan Tabel 6 dan table 7 maka diperoleh discernibility matrix dan discernibility matrix modulo $D$ untuk mendapatkan reduct dan rule keputusan seperti terlihat pada tabel 8 dan tabel 9. Discernibility matrix hanya memperhatikan atribut kondisinya saja seperti terlihat pada tabel 8.

Tabel 8. Discernibility Matrix

\begin{tabular}{|c|c|c|c|c|c|c|c|c|c|c|c|c|c|c|c|c|}
\hline & EC1 & EC2 & EC3 & EC4 & EC5 & EC6 & EC7 & EC8 & EC9 & EC10 & EC11 & EC12 & EC13 & EC14 & EC15 & EC16 \\
\hline EC1 & & $\mathrm{KL}$ & KLM & KLM & KLM & KLM & KLM & KLM & KLM & KLM & LM & LM & KLM & LM & KLM & KLM \\
\hline EC2 & $\overline{K L}$ & & KM & KM & KLM & KLM & KLM & KLM & KM & $\mathrm{KM}$ & $\mathrm{KM}$ & $\mathrm{KM}$ & KLM & $\mathrm{KM}$ & LM & KLM \\
\hline EC3 & KLM & $\mathrm{KM}$ & & $\mathrm{KM}$ & KLM & $\mathrm{KL}$ & $\mathrm{KL}$ & LM & $\mathrm{M}$ & KM & $\mathrm{K}$ & $\mathrm{KL}$ & $\mathrm{KLM}$ & KLM & $\mathrm{KL}$ & KLM \\
\hline EC5 & KLM & KLM & KLM & LM & & LM & $\mathrm{KM}$ & KM & KLM & KLM & KLM & KLM & KLM & $\mathrm{KL}$ & KLM & $\mathrm{KM}$ \\
\hline EC6 & KLM & KLM & $\mathrm{KL}$ & LM & LM & & $\mathrm{KL}$ & KLM & KLM & KLM & $\mathrm{KL}$ & KLM & KLM & KLM & $\mathrm{K}$ & KLM \\
\hline EC7 & KLM & KLM & $\mathrm{KL}$ & KLM & KM & $\mathrm{KL}$ & & KM & KLM & LM & $\mathrm{KL}$ & KLM & $\mathrm{KL}$ & KLM & $\mathrm{KL}$ & KM \\
\hline EC8 & KLM & KLM & LM & KLM & $\mathrm{KM}$ & KLM & $\mathrm{KM}$ & & $\mathrm{L}$ & $\mathrm{KL}$ & KLM & $\mathrm{KL}$ & KM & KLM & KLM & KM \\
\hline EC9 & KLM & $\mathrm{KM}$ & $M$ & $\mathrm{KM}$ & KLM & KLM & KLM & $\mathrm{L}$ & & $\mathrm{K}$ & KLM & $\mathrm{KL}$ & KLM & KLM & KLM & LM \\
\hline EC10 & KLM & $\mathrm{KM}$ & $\mathrm{KM}$ & $\mathrm{KM}$ & KLM & KLM & LM & $\mathrm{KL}$ & $\mathrm{K}$ & & $\mathrm{KM}$ & $\mathrm{K}$ & KLM & $\mathrm{KM}$ & KLM & KLM \\
\hline EC11 & LM & $\mathrm{KM}$ & $\mathrm{K}$ & KM & KLM & $\mathrm{KL}$ & $\mathrm{KL}$ & KLM & KLM & KM & & $M$ & KLM & KM & KLM & KLM \\
\hline EC12 & LM & $\mathrm{KM}$ & $\mathrm{KL}$ & KM & KLM & KLM & KLM & $\mathrm{KL}$ & $\mathrm{KL}$ & $\mathrm{K}$ & $M$ & & KLM & KM & KLM & KLM \\
\hline EC13 & KLM & KLM & KLM & $\mathrm{KL}$ & KLM & KLM & $\mathrm{KL}$ & KM & KLM & KLM & KLM & KLM & & KLM & KLM & KM \\
\hline EC14 & LM & $\mathrm{KM}$ & KLM & $\mathrm{KM}$ & $\mathrm{KL}$ & KLM & KLM & KLM & KLM & $\mathrm{KM}$ & $\mathrm{KM}$ & $\mathrm{KM}$ & $\mathrm{KLM}$ & & KLM & KLM \\
\hline EC15 & KLM & LM & $\mathrm{KL}$ & KLM & KLM & $\mathrm{K}$ & $\mathrm{KL}$ & KLM & KLM & KLM & KLM & KLM & KLM & KLM & & KLM \\
\hline EC16 & KLM & KLM & KLM & KLM & $\mathrm{KM}$ & KLM & KM & $\mathrm{KM}$ & LM & KLM & KLM & KLM & $\mathrm{KM}$ & KLM & KLM & \\
\hline
\end{tabular}

d. Discernibilty Matrix Modulo D

Matrik ini merupakan penyederhanaan matrik discernibility dengan cara membandingkan semua atribut, yaitu atribut kondisi dan atribut keputusan. 
Tabel 9. Discernibility Matrix Modulo D

\begin{tabular}{|c|c|c|c|c|c|c|c|c|c|c|c|c|c|c|c|c|}
\hline & EC1 & EC2 & EC3 & EC4 & EC5 & EC6 & EC7 & EC8 & EC9 & EC10 & EC11 & EC12 & EC13 & EC14 & EC15 & EC16 \\
\hline EC1 & & $\mathrm{KL}$ & KLM & KLM & KLM & KLM & KLM & & KLM & KLM & LM & LM & & LM & $\mathrm{KLM}$ & \\
\hline EC2 & $\mathrm{KL}$ & & KM & KM & & KLM & & KLM & & & KM & & KLM & & & KLM \\
\hline EC3 & KLM & $\mathrm{KM}$ & & & KLM & & $\mathrm{KL}$ & LM & $M$ & KM & & $\mathrm{KL}$ & KLM & KLM & $\mathrm{KL}$ & KLM \\
\hline EC4 & KLM & KM & & & LM & & KLM & KLM & KM & KM & & KM & $\mathrm{KL}$ & KM & KLM & KLM \\
\hline EC5 & KLM & & KLM & LM & & LM & & $\mathrm{KM}$ & & & KLM & & KLM & & & KM \\
\hline EC6 & KLM & KLM & & & LM & & $\mathrm{KL}$ & KLM & KLM & KLM & & KLM & KLM & KLM & $\mathrm{K}$ & KLM \\
\hline EC7 & KLM & & $\mathrm{KL}$ & KLM & & $\mathrm{KL}$ & & $\mathrm{KM}$ & & & $\mathrm{KL}$ & & $\mathrm{KL}$ & & & KM \\
\hline EC8 & & KLM & LM & KLM & KM & KLM & KM & & $\mathrm{L}$ & $\mathrm{KL}$ & KLM & $\mathrm{KL}$ & & KLM & KLM & \\
\hline EC9 & KLM & & $M$ & KM & & KLM & & $\mathrm{L}$ & & & KLM & & KLM & & & LM \\
\hline EC10 & KLM & & KM & KM & & KLM & & $\mathrm{KL}$ & & & KM & & KLM & & & KLM \\
\hline EC11 & LM & KM & & & KLM & & $\mathrm{KL}$ & KLM & KLM & KM & & $M$ & KLM & KM & KLM & KLM \\
\hline EC12 & LM & & $\mathrm{KL}$ & KM & & KLM & & $\mathrm{KL}$ & & & $M$ & & KLM & & & KLM \\
\hline EC13 & & KLM & KLM & $\mathrm{KL}$ & KLM & KLM & $\mathrm{KL}$ & & KLM & KLM & KLM & KLM & & KLM & KLM & \\
\hline EC14 & LM & & KLM & KM & & KLM & & KLM & & & KM & & KLM & & & KLM \\
\hline EC15 & KLM & & $\mathrm{KL}$ & KLM & & $\mathrm{K}$ & & KLM & & & KLM & & KLM & & & KLM \\
\hline EC16 & & KLM & KLM & KLM & KM & KLM & KM & & LM & KLM & KLM & KLM & & KLM & KLM & \\
\hline
\end{tabular}

e. Reduct

Berdasarkan tabel 9 maka dapat disusun reduct yang merupakan himpunan minimal dari atribut dengan memperhatikan operasi Boolean seperti terlihat pada table 10.

\begin{tabular}{|c|c|c|c|}
\hline CLASS & CNF of Bolean Function & Prime Implicant & Reducts \\
\hline $\mathrm{EC}_{1}$ & $(\mathrm{~K} \vee \mathrm{L} \vee \mathrm{M}) \wedge(\mathrm{LVM}) \wedge(\mathrm{K} \vee \mathrm{L})$ & $(\mathrm{L}) \vee(\mathrm{M} \wedge \mathrm{K})$ & $\{\mathrm{L}\}\{\mathrm{M}, \mathrm{K}\}$ \\
\hline $\mathrm{EC}_{2}$ & $(\mathrm{~K} \vee \mathrm{L} \vee \mathrm{M}) \wedge(\mathrm{K} \vee \mathrm{M}) \wedge(\mathrm{K} \vee \mathrm{L})$ & $(\mathrm{K}) \vee(\mathrm{L} \wedge \mathrm{M})$ & $\{\mathrm{K}\}\{\mathrm{L}, \mathrm{M}\}$ \\
\hline $\mathrm{EC}_{3}$ & $(\mathrm{~K} \vee \mathrm{LVM}) \wedge(\mathrm{K} \vee M) \wedge(\mathrm{KVL}) \wedge(\mathrm{LVM}) \wedge(\mathrm{M})$ & $(\mathrm{M}) \vee(\mathrm{K} \wedge \mathrm{L})$ & $\{\mathrm{M}\}\{\mathrm{K}, \mathrm{L}\}$ \\
\hline $\mathrm{EC}_{4}$ & $(\mathrm{~K} \vee \mathrm{LVM}) \wedge(\mathrm{K} \vee \mathrm{M}) \wedge(\mathrm{LVM}) \wedge(\mathrm{K} \vee \mathrm{L})$ & $(\mathrm{K} \wedge \mathrm{L}) \vee(\mathrm{M} \wedge \mathrm{L}) \vee(\mathrm{K} \wedge \mathrm{M})$ & $\{\mathrm{K}, \mathrm{L}\}\{\mathrm{M}, \mathrm{L}\}\{\mathrm{K}, \mathrm{M}\}$ \\
\hline $\mathrm{EC}_{5}$ & $(K \vee L \vee M) \wedge(L \vee M) \wedge(K \vee M)$ & $(\mathrm{K} \wedge \mathrm{L}) \vee(\mathrm{M})$ & $\{\mathrm{K}, \mathrm{L}\}\{\mathrm{M}\}$ \\
\hline $\mathrm{EC}_{6}$ & $(\mathrm{~K} \vee L \vee M) \wedge(L \vee M) \wedge(K \vee L) \wedge(L)$ & (L) & $\{\mathrm{L}\}$ \\
\hline $\mathrm{EC}_{7}$ & $(\mathrm{~K} \vee \mathrm{L} \vee \mathrm{M}) \wedge(\mathrm{K} \vee \mathrm{M}) \wedge(\mathrm{K} \vee \mathrm{L})$ & $(\mathrm{K}) \vee(\mathrm{L} \wedge \mathrm{M})$ & $\{K\}\{L, M\}$ \\
\hline $\mathrm{EC}_{8}$ & $(\mathrm{~K} \vee \mathrm{L} \vee M) \wedge(\mathrm{LVM}) \wedge(\mathrm{K} \vee \mathrm{M}) \wedge(\mathrm{L})$ & $(\mathrm{K} \wedge \mathrm{L}) \vee(\mathrm{M} \wedge \mathrm{L})$ & $\{\mathrm{K}, \mathrm{L}\}\{\mathrm{M}, \mathrm{L}\}$ \\
\hline $\mathrm{EC}_{9}$ & $(\mathrm{~K} \vee \mathrm{LVM}) \wedge(\mathrm{K} \vee \mathrm{M}) \wedge(\mathrm{LVM}) \wedge(\mathrm{L})$ & $(\mathrm{L}) \vee(\mathrm{K} \vee \mathrm{M})$ & $\{L\}\{K, M\}$ \\
\hline $\mathrm{EC}_{10}$ & $(K \vee L \vee M) \wedge(K \vee M) \wedge(K \vee L)$ & $(\mathrm{K}) \vee(\mathrm{L} \wedge \mathrm{M})$ & $\{\mathrm{K}\}\{\mathrm{L}, \mathrm{M}\}$ \\
\hline $\mathrm{EC}_{11}$ & $(\mathrm{KVLVM}) \wedge(\mathrm{K} \vee \mathrm{M}) \wedge(\mathrm{KVL}) \wedge(\mathrm{LVM}) \wedge(\mathrm{M})$ & $(\mathrm{M} \wedge \mathrm{K}) \vee(\mathrm{M} \wedge \mathrm{L})$ & $\{\mathrm{M}, \mathrm{K}\}\{\mathrm{M}, \mathrm{L}\}$ \\
\hline $\mathrm{EC}_{12}$ & $(\mathrm{KVLVM}) \wedge(\mathrm{KVM}) \wedge(\mathrm{KVL}) \wedge(\mathrm{LVM}) \wedge(\mathrm{M})$ & $(\mathrm{M} \wedge \mathrm{K}) \vee(\mathrm{M} \wedge \mathrm{L})$ & $\{\mathrm{M}, \mathrm{K}\}\{\mathrm{M}, \mathrm{L}\}$ \\
\hline $\mathrm{EC}_{13}$ & $(\mathrm{~K} \vee L \vee M) \wedge(K \vee L)$ & $(\mathrm{KVL})$ & $\{\mathrm{K}\}\{\mathrm{L}\}$ \\
\hline $\mathrm{EC}_{14}$ & $(\mathrm{~K} \vee L \vee M) \wedge(K \vee M) \wedge(L \vee M)$ & $(\mathrm{L} \wedge \mathrm{K}) \vee(\mathrm{M})$ & $\{\mathrm{L}, \mathrm{K}\}\{\mathrm{M}\}$ \\
\hline $\mathrm{EC}_{15}$ & $(\mathrm{~K} \vee L \vee M) \wedge(K \vee L) \wedge(k)$ & $(\mathrm{K})$ & $\{\mathrm{K}\}$ \\
\hline $\mathrm{EC}_{16}$ & $(\mathrm{KVLVM}) \wedge(\mathrm{LVM})$ & (LVM) & $\{\mathrm{L}\}\{\mathrm{M}\}$ \\
\hline
\end{tabular}

f. Generating Rules

Berdasarkan reduct pada table 10 maka dapat disusun generating rule yang digunakan untuk mengklasifikasi jumlah mahasiswa yang memiliki peluang yang sama dan yang berbeda.

\begin{tabular}{|c|c|}
\hline \multicolumn{2}{|c|}{ Reduct } \\
\hline & $\{L\},\{M, K\}$ \\
\hline & $\{K\},\{L, M\}$ \\
\hline 3) & $\{\mathrm{M}\},\{\mathrm{K}, \mathrm{L}\}$ \\
\hline 4) & $\{\mathrm{K}, \mathrm{L}\},\{\mathrm{M}, \mathrm{L}\},\{\mathrm{K}, \mathrm{M}\}$ \\
\hline 5) & $\{\mathrm{K}, \mathrm{L}\},\{\mathrm{M}\}$ \\
\hline 6) & $\{\mathrm{L}\}$ \\
\hline 7) & $\{\mathrm{K}\},\{\mathrm{L}, \mathrm{M}\}$ \\
\hline 8) & $\{\mathrm{K}, \mathrm{L}\},\{\mathrm{M}, \mathrm{L}\}$ \\
\hline & $\{\mathrm{L}\},\{\mathrm{K}, \mathrm{M}\}$ \\
\hline 10) & $\{K\},\{M, L\}$ \\
\hline 11) & $\{\mathrm{M}, \mathrm{K}\},\{\mathrm{M}, \mathrm{L}\}$ \\
\hline 12) & $\{\mathrm{M}, \mathrm{K}\},\{\mathrm{M}, \mathrm{L}\}$ \\
\hline 13) & $\{K\},\{L\}$ \\
\hline 14) & $\{L, K\},\{M\}$ \\
\hline 15) & $\{K\}$ \\
\hline 16) & $\{\mathrm{L}\},\{\mathrm{M}\}$ \\
\hline
\end{tabular}

ISSN $2476-8812$

\begin{tabular}{|c|c|c|c|c|}
\hline \multicolumn{5}{|c|}{ Equivalence Class } \\
\hline Sampel & $K$ & $L$ & $M$ & $\bar{N}$ \\
\hline S1 & $\mathrm{A}$ & $\mathrm{D}$ & $\mathrm{C}$ & 1 \\
\hline S2 & C & $\mathrm{F}$ & C & 2 \\
\hline S3 & $\mathrm{D}$ & $\mathrm{F}$ & $\mathrm{F}$ & 3 \\
\hline S4 & $F$ & $F$ & $B$ & 3 \\
\hline $\mathrm{S} 5$ & $\mathrm{~F}$ & $E$ & $\mathrm{~A}$ & 2 \\
\hline S6 & $\mathrm{F}$ & $B$ & $\mathrm{~F}$ & 3 \\
\hline S7 & $E$ & $E$ & $\mathrm{~F}$ & 2 \\
\hline S8 & $\mathrm{D}$ & $E$ & $E$ & 1 \\
\hline S9 & $\mathrm{D}$ & $F$ & $E$ & 2 \\
\hline S10 & $E$ & $\mathrm{~F}$ & $E$ & 2 \\
\hline S11 & $\mathrm{A}$ & $\mathrm{F}$ & $\mathrm{F}$ & 3 \\
\hline $\mathrm{S} 12$ & $\mathrm{~A}$ & $F$ & $E$ & 2 \\
\hline $\mathrm{S} 13$ & $B$ & $E$ & $B$ & 1 \\
\hline S14 & $A$ & $\mathrm{~F}$ & $\mathrm{~A}$ & 2 \\
\hline S15 & $C$ & $B$ & $\mathrm{~F}$ & 2 \\
\hline $\mathrm{S} 16$ & $\mathrm{D}$ & $E$ & $\mathrm{D}$ & 1 \\
\hline
\end{tabular}

Karmila Suryani: Prediksi Peluang Kelulusan Mahasiswa(...) 
Berikut dijelaskan knowledge yang dihasilkan berdasarkan reduct dan equivalence class, dimana atribut kondisi K (Nilai Word), L (Nilai Excel) dan M (Nilai Power Point), sedangkan atribut keputusan N (Peluang Lulus).

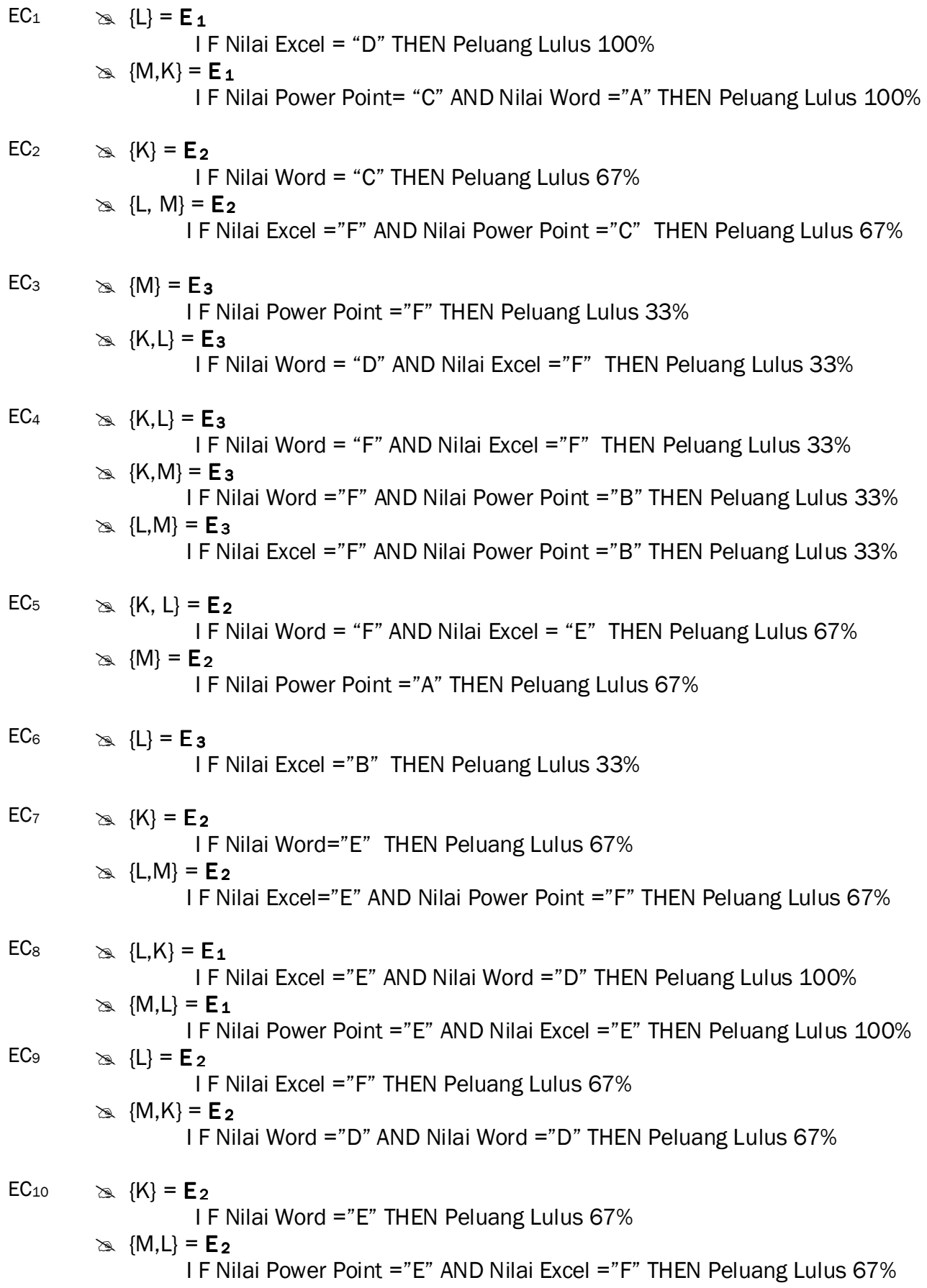




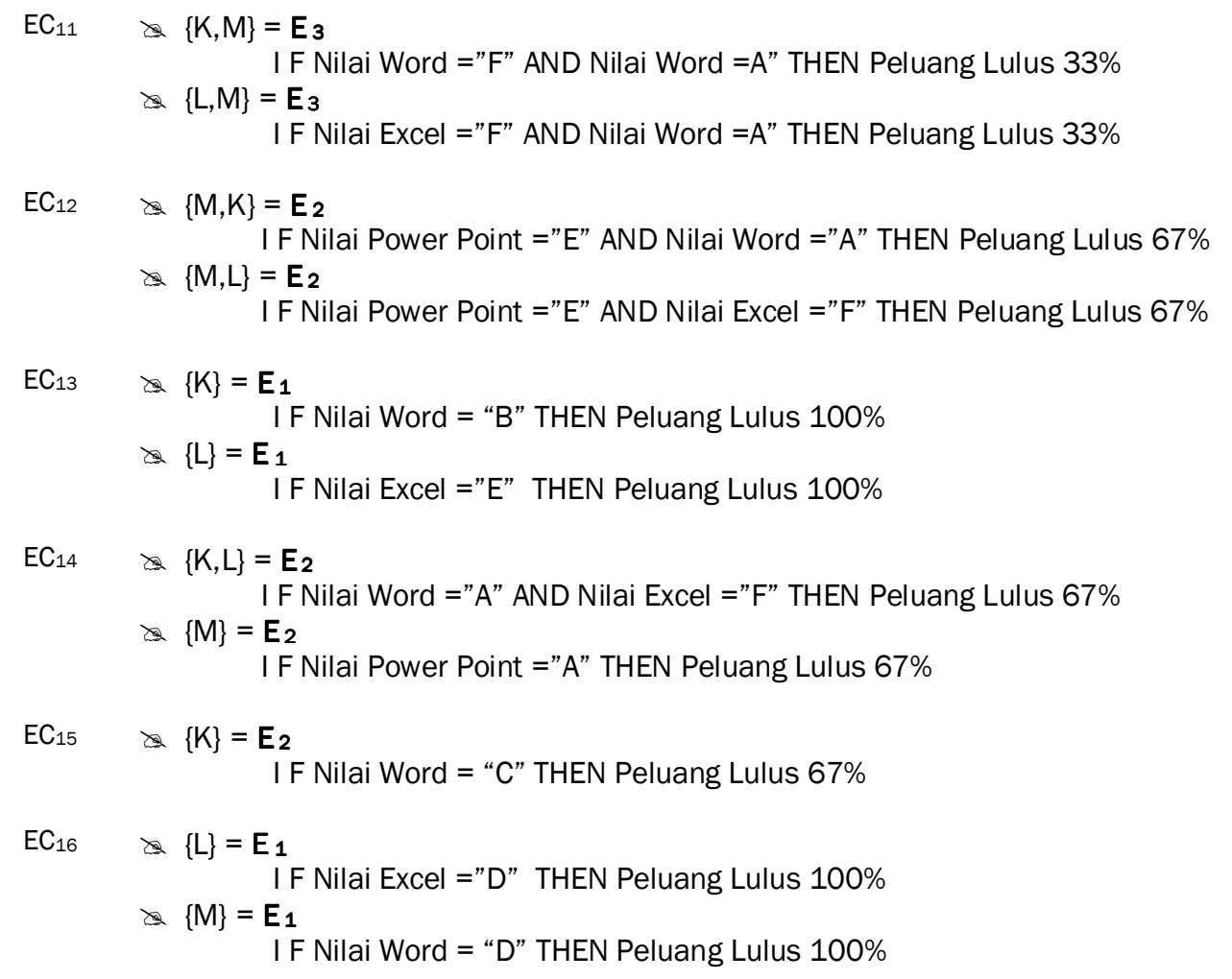

\section{KESIMPULAN}

Setelah dilakukan analisa dengan teori Rough Set, maka dari 18 mahasiwa yang menjadi sampel didapat 4 orang mahasiswa berpeluang lulus $100 \%$ dengan knowledge jika nilai word berkisar antara 51 sampai 86 , nilai Excel berkisar antara 55 sampai 66 dan nilai Power Point berkisar antara 55 sampai 80 . Mahasiswa yang berpeluang lulus $67 \%$ sebanyak 8 orang dengan knowledge, jika nilai word berkisar antara 25 sampai 86, nilai excel berkisar antara 34 sampai 55 dan nilai power point berkisar antara 35 sampai 86. Selebihnya mahasiswa hanya berpeluang lulus sebesar $33 \%$ dengan knowledge, jika nilai word berkisar anta 66 sampai 85, nilai excel berkisar antara 20 sampai 76 dan nilai power point berkisar antar 35 sampai 80.

\section{REFERENSI}

[1] Arifian,M.E dan RB Fajriya Hakim, 2015, Penerapan Metode Rough Set pada Laka Lantas Sepeda Motor di Kota Magelang tahun 2014, Prosiding Seminar Nasional Matematika dan Pendidikan Matematika UMS, Semarang, 2015

[2] Puspitasari,D dan RB Fajriya Hakim, 2015, Aturan Pengambilan Keputusan pada Kecelakaan Lalu lintas di Kabupaten Sleman menggunakan Algoritma IF-Then Rules pada Metode Rough Set, Prosiding Seminar Nasional Matematika dan Pendidikan Matematika UMS, Semarang, 2015. Munir, 2014, Kerangka Kompetensi TIK bagi Guru, Alfa Beta, Bandung

[4] Sugiyono, 2008, Metode Penelitian Pendidikan Pendekatan Kuantitatif, Kualitatif dan R\&D, Alfabeta, Bandung.

[5] Suratiningsih, 2013, Min-Min Roughness(MMR) untuk klasterisasi data kategori, studi kasus kecemasan belajar pada mahasiswa tahun pertama dan keempat di UAD, Jurnal Konvergensi, Vol 3, No 2, Oktober ,pp:19-32

[6] Suryani Karmila, 2012, Penerapan Teori Rough Set untuk Menentukan Kelayakan Pemberian Kredit Penjualan Ban Good Year. Jurnal Sigmatek, Volume 3 No 1, No1, Vol 3, 23-31

[7] Suryani Karmila, 2015, Penerapan Teori Rough Set untuk Menentukan Distribusi persentase Terbaik bagi Mata Kuliah di Jurusan Pendidikan Teknik Informatika dan Komputer (PTIK) Universitas Bung Hatta, Prosiding Semonar Nasional Pendidikan Teknik Informatika 1 (SNPI1) STKIP, Padang, April 